\title{
THE USE OF OSCILLATORIA PSEUDOGEMINATA IN DOMESTIC WASTEWATER TREATMENT IN AL- DIWANIYA PROVINCE, IRAQ
}

\author{
Wurood Jasim Mohammed \\ Department of Biology \\ University of AL- Qadisiyah, \\ AL-Diwanyia Province, Iraq
}

\author{
Abeer Hamoodi Jabbar \\ Department of Biology \\ University of AL- Qadisiyah, \\ AL-Diwanyia Province, Iraq
}

\author{
Muqdad Irhaeem Kadhim \\ Department of Chemistry \\ University of AL- Qadisiyah, \\ AL-Diwanyia Province, Iraq
}

\author{
Mustafa Hamoodi Jabbar \\ Department of Environmental \\ University of AL- Qadisiyah, \\ AL-Diwanyia Province, Iraq
}

\author{
Hussein H. Al-Shafai \\ Department of Biology \\ University of AL- Qadisiyah, \\ AL-Diwanyia Province, Iraq
}

\begin{abstract}
The study included testing the susceptibility of algae (Oscillatoria pseudogeminata) in removing phytonutrients consisting of ammonia, nitrite, nitrates, active phosphorus, and total phosphorous. As well as the ability of these algae to reduce the chemical requirement of oxygen from the domestic wastewater, in addition to its effectiveness in removing some heavy metals (iron, copper, lead, nickel). This algae was used in the form of the Unialgal culture obtained from the algae plant in the fish department. The results indicated that the efficiency of $O$. pseudogeminata was better than the other two types. Where the removal was complete $(\mathbf{1 0 0 \%})$ for both ammonia and active phosphorus during the seventh day of treatment. 79\% of total phosphorous was removed after ten days. The ability of the algae was lower in removing nitrites $\mathbf{( 7 0 \% )}$ and nitrates $(80 \%)$, and the algae was able to reduce the chemical requirement of oxygen to $80 \%$ during the treatment period. The heavy metals were removed $100 \%$ for iron, copper, lead and nickel on the ninth day.
\end{abstract}

Key words : Water pollution, Oscillatoria pseudogeminata

\section{INTRODUCTION}

Water pollution is defined as the increase in chemical, biological or physical factors in a concentration or in a way that makes water harmful to humans, aquatic organisms, or properties. There are those who see that water is polluted when it is not of a quality with specifications that are compatible with the highest requirements that a person needs, namely drinking mainly, then all other personal uses and natural uses, including recreational purposes as well. Natural pollution means the appearance of natural ingredients in water, such as inorganic salts of all kinds, silt, sulfur gases dissolved, heat, radiation, and others in more quantities than normal. As for human pollution, it is the changes that occur in water due to human activity, whether industrial or agricultural, or as a result of daily uses of this water by humans. Water in nature is exposed to the danger of the appearance of foreign compounds such as pesticides, or an increase in one or more other natural components such as salts from their natural limits. As is well known, water bodies have the ability to self-purify from foreign pollutants (AlOmar,2000).

Due to the increased volumes and concentrations of the fluxes, it has become impossible for water bodies to perform this process (Rupert et al., 1996). Domestic wastewater, which is produced by cities, is a major source of water pollution. Consequently, the ill-considered and unregulated use of untreated wastewater has negative consequences for the environment and public health. Most studies conducted on the use of wastewater for agricultural purposes indicate that there is a difference in the nature and contents of these substances according to their sources (Al-Khair, 2001), and there is an urgent need to identify their contents before using them, and may contain high concentrations of some toxic elements that exceed their natural limits, It may also contain pathogens that may directly or indirectly cause environmental risks to plants and their consuming neighborhoods, even though they contain some nutrients necessary for plant growth (Al-Hadithi et al ., 2001). Treatments that started with simple traditional methods have evolved into advanced treatment methods and sterilization, as some countries have reached the production of safe drinking water from wastewater according to the international standards for drinking water (Al-Khair, 2001). As a result of the rapid population development that increased wastewater and that was accompanied by partial treatment, it 


\section{International Journal of Engineering Applied Sciences and Technology, 2019 \\ Vol. 4, Issue 8, ISSN No. 2455-2143, Pages 400-403 \\ Published Online December 2019 in IJEAST (http://www.ijeast.com)}

led to an increase in nutrient load and caused the problem of nutritional enrichment (Eutrophication Diederik, 1999) and 2001 (Victor, et al.). One of these methods is the use of microalgae, as algae farms have been used to remove nutrients from wastewater rich in nitrogen and phosphorus (Tam et al., 1994) as a third stage of treatment (Lavoie and De la Noüe, 1985 and Noüe, 1993 Talbot and De la Canizares et al., 1994) These wastes were also used as a culture medium for algae growth Removal of nutrients and oxygen production, which improves the quality of Almtdvqat and this growth is accompanied by the production of live mass of algae as possible to take advantage of them for several purposes (De la Noüe, et al., 1992).

\section{MATERIALS AND METHODS}

Waste water from the final sedimentation ponds was used as culture media for the development of the mentioned algae by culture algae in sterile wastewater once and not sterilized again in constant laboratory conditions at a temperature of $20 \square 20$ and the intensity of illumination 260 microsinstein / $\mathrm{m} 2 /$ second and in a light system 8:16 hours of lighting: Dark using fixed farms.

\section{RESULTS AND DISCUSSION}

The study aims to identify the efficiency of the Oscillatoria pseudogeminata in Removing the nutrients (nitrogen and phosphorous) from domestic waste water and Removing heavy metals (nickel, lead, iron and copper) from this also determine the living mass of algae $\quad$ Comparing the removal process with sterile and non-sterile wastewater,

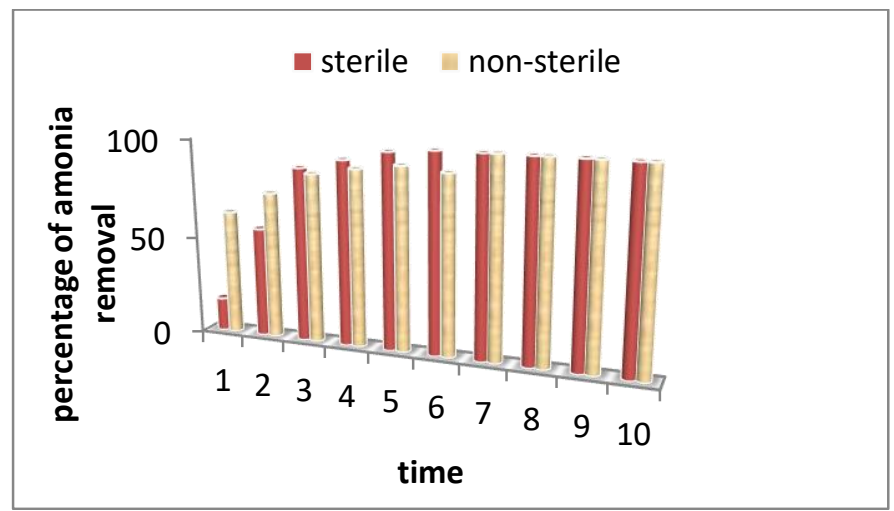

Figure (1): Percentage of removing ammonia from sterile and non-sterile wastewater Treatment with Oscillatoria pseudogeminata

The current study showed that removal ratio of ammonia from sterile and non sterile wastewater was perfect when this treatment with the algae Oscillatoria pseudogeminata and this means that we can use this algae in treatment of water, but Extensive studies must be done to find out whether these algae affected human health or excrete harmful substances in order to make sure and thus use them to sterilize household wastewater and get rid of some harmful pollutants harmful to humans and living organisms.

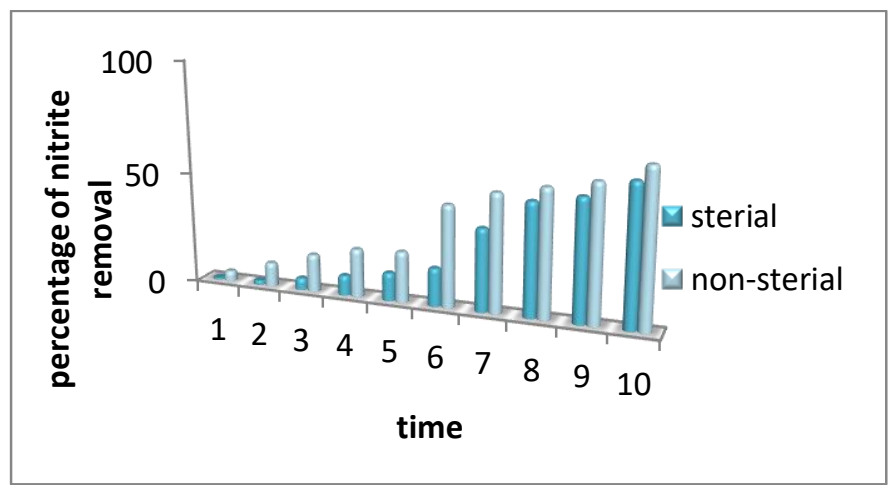

Figure (2): Percentage of nitrite removal from sterile and non-sterile wastewater Treatment with Oscillatoria pseudogeminata 


\section{International Journal of Engineering Applied Sciences and Technology, 2019 \\ Vol. 4, Issue 8, ISSN No. 2455-2143, Pages 400-403 \\ Published Online December 2019 in IJEAST (http://www.ijeast.com)}

Table (1): Biomass in terms of cell number, absorbance, dry weight, growth rate, and doubling time of the algae culture

Oscillatoria pseudogeminata in sterile wastewater.

\begin{tabular}{|l|l|l|l|l|l||}
\hline $\begin{array}{c}\text { Time of } \\
\text { multiplicat } \\
\text { ion( hour) }\end{array}$ & $\begin{array}{c}\text { growth } \\
\text { rate }\end{array}$ & $\begin{array}{l}\text { Dry weight } \\
\text { (Lt. Mg) }\end{array}$ & $\begin{array}{c}\text { Absorbance } \\
\text { nanometer }\end{array}$ & cell $\mathbf{x}^{\mathbf{6}} \mathbf{1 0}$ mili & day( time) \\
\hline \hline 0.00 & 0.01 & 0.044 & 0.033 & 0.4 & 0 \\
\hline 72.20 & 0.01 & 0.045 & 0.044 & 0.36 & 1 \\
\hline 38.21 & 0.180 & 0.063 & 0.055 & 0.5 & 2 \\
\hline 48.9 & 0.99 & 0.077 & 0.090 & 0.4 & 3 \\
\hline 60.12 & 0.100 & 0.085 & 0.111 & 0.9 & 4 \\
\hline 45.11 & 0.91 & 0.089 & 0.120 & 1.3 & 5 \\
\hline 58.12 & 0.100 & 0.110 & 0.150 & 1.7 & 6 \\
\hline 59.22 & 0.130 & 0.120 & 0.166 & 1.9 & 7 \\
\hline 60.32 & 0.150 & 0.133 & 0.169 & 2.5 & 8 \\
\hline 63.13 & 0.115 & 0.145 & 0.170 & 3.1 & 9 \\
\hline 66.12 & 0.130 & 0.152 & 0.180 & 4.1 & 10 \\
\hline
\end{tabular}

Table (2): Biomass in terms of cell number, absorbance, dry weight, growth rate, and doubling time of the algae culture Oscillatoria pseudogeminata in non-sterile wastewater.

\begin{tabular}{|c|c|c|c|c|c|}
\hline $\begin{array}{c}\text { Time of } \\
\text { multiplicat } \\
\text { ion hour }\end{array}$ & $\begin{array}{c}\text { Growth } \\
\text { rate }\end{array}$ & $\begin{array}{l}\text { Dry weight } \\
\text { ))Lt. } \mathrm{Mg}(\end{array}$ & $\begin{array}{l}\text { Absorbance } \\
\text { )nanometer( }\end{array}$ & cell x مليلتر 10 |ملتر & Time ) day( \\
\hline 0.00 & 0.00 & 0.056 & 0.08 & 0.13 & 0 \\
\hline 55.2 & 0.132 & 0.016 & 0.09 & 0.35 & 1 \\
\hline 48.5 & 0.142 & 0.07 & 0.133 & 0.15 & 2 \\
\hline 41.2 & 0.173 & 0.091 & 0.172 & 1.0 & 3 \\
\hline 42.3 & 0.165 & 0.11 & 0.196 & 1.12 & 4 \\
\hline 49.2 & 0.141 & 0.13 & 0.230 & 1.26 & 5 \\
\hline 53.7 & 0.132 & 0.149 & 0.250 & 1.19 & 6 \\
\hline 57.9 & 0.124 & 0.150 & 0.271 & 3.3 & 7 \\
\hline 64.3 & 0.111 & 0.153 & 0.291 & 4.3 & 8 \\
\hline 69.2 & 0.107 & 0.152 & 0.280 & 4.7 & 9 \\
\hline 81.05 & 0.115 & 0.141 & 0.271 & 4.8 & 10 \\
\hline
\end{tabular}

\section{CONCLUSION}

The study included the use of algae to purify water from heavy metals and filter domestic wastewater. Also, in future studies, other types of algae can be used in water purification.

\section{REFERENCE}

1-Al-Hadithi, A H K and Abdul-Razzaq, I B and AlGhurery, S M and Al-Ubaidi, H S (2001). The effect of adding sewage sewage on the content of small and heavy elements in soil and vegetation, the seventh Iraqi technological conference, University of Technology Baghdad-Iraq 457466
2-Al-Khair, A (2001). A Modern Method in Sewage Treatment and Use in Irrigation, The Seventh Iraqi Technology Conference, University of Technology, Baghdad, Iraq. 264-276

3-Al-Omar, M A (2000). Environmental Pollution. First edition, Amman Al-Awa'il Publishing House, p. 223

4-Adey,W.; Luckett,C. and Jensen,K. (1993).Phosphorus removal from natural water using controled algal production. Society for Ecological Restration.p,29-39

5- Becker, E.W.(1983).Limitations of heavy metal removal from waste- water by means of algae. Water Res. 17, (4) ,459466 . 


\section{International Journal of Engineering Applied Sciences and Technology, 2019 \\ Vol. 4, Issue 8, ISSN No. 2455-2143, Pages 400-403 \\ Published Online December 2019 in IJEAST (http://www.ijeast.com)}

6- Blier,R.; Laliberte,G. and De la Noüe,J. (1996). Production of the Cynobacterium Phormidium bohneri in parall with equration of a dairy anaerobic effluent. Process Biochem.,31,(6),587-593.

7-Boney,A.D.(1975). Phytoplankton. Camelot Press Ltd, Southampton.116 pp.

8-Canizares R.O. and Dominguez A. (1993). Growth of Spirulina maxima on swine waste, Biores.Technol. 45, 73-75. 9-Canizares R.O.; Dominguez A. R.; Cruz M.S. and Rios,L.E. (1995). Chemical composition of cyanobacteria grown in diluted treated swine wastewater, Biores.Technol. 51, $111-$ 116.

10- De la Noüe J. and Eidhin D. (1988) Improved performance of intensive semicontinous cultures of Scenedesmus by biomass recirculation, Biotechnol. Bioeng., 31, 397 - 406.

11-Droop, M. P. (1974). The nutrient status of the algal cells in continuous culture. J. Mar. Biol. Ass. 54, 825 - 855.

12-Evonne,P.Y.T.; Warwick,F.V.; Daniel,P.; Paul,L. and De la Noüe ,J. (1997).Polor cyanobacteria versus green algae for tertiary wast-water treatment in cool climates.J.Appl.Phycol.9:371-381.

13-Fogg, G. E.; Stewart, W.D.P.; Fay, P. and Walsby,A.E.(1973). The blue green algae. London Academic press.pp 77-91.

14-Furukawa,K.and Hashimoto,S. (1989).Nutrient removal from secondary effluent by filamentous algae.J.Ferment Bioing.67,62-69.

15-Henry, R; Tundisi,J.G. and Curi P.R. (1984). Effects of phosphorus and nitrogen enrichment on the phytoplankton in a tropical reservoir (Lobo reservoir, Brazil) Hydrobiol. 118, $177-185$.

16-Kassim,T.I.and Al-Lami,A.A. (1999). Possible use of microgreen algae to remove phosphate and nitrate from wastewater.Iraqi J.of Biology 1(1),11-16.

17-Munda,I.M. and Hudnik,V.(1986).Growth response of Fucus vesiculosus to heavy metals, singly and in dual combinations; as related to accumulation. Botan. Mar.,29, 401

-412 .

18-Patrick,R.(1977). Ecology of fresh water diatoms and diatomcommunities .In: The biology of diatoms (ed.)by Werner,D. Botanical monographs. Univ. Calif. Press. Berkeley,pp.284.332.

19-Reynolds,C.S.(1984).The ecology of fresh water phytoplankton cambridge Univ. press. Cambridge. 384 pp.

20-Shelef,G.(1982).High rate algae ponds for wastwater treatment and protein production. Wat. Sci. Tech., 14, 439-452. 21-Tam,N.F.Y.;Lau,P.S.and Wong,Y.S.(1994).Wastewater inorganic $\mathrm{N} \& \mathrm{P}$ removal by immobilized Chlorella vulgaris.Wat. Sci.Tech.30, 6, 369-374.

22-Kadhim M , I( 2019). Endocrine disrupting Bisphenol A detection in different water samples in Iraq Journal of Physics: Conf. Series 1294 (2019) 052045.

23-Vymazal, J.(1990). Toxicity and accumulation of lead with respect to algae and cyanobacteria: A review. Acta Hydrochem. Hydrobiol., 18 (5): 513 - 535.
24-Kadhim M , I, . Jabbar M , H . Mohammed W, J . AlShamkhee Z A K . Obayes I, S . Jabbar A H.(2019). Isolation and Identification of different microorganisms in the soil in the Diwaniyah city in Iraq , Pramana Research Journal Volume 9, Issue 12, 2019 ISSN NO: 2249-2976.

25-Kadhim M , I ( 2015).Synthesis and biological evaluations of new phenothiazine derivatives journal of al-qadisiyah for pure science(quarterly

26-Victor, J.N.; Domenico,V.; Mario, N.; Pablo, P. Alejandra, M.; and Martin, G. (2001).Nitrogen budget in Scenedesmus obliquus cultures with artificial wastewater. Biores. Technol. 78,161-164

27-Kadhim M , I, . Jabbar M , H . Mohammed W , J . AlShamkhee Z A K . Obayes I , S . Jabbar A H.(2019). ANTIBIOTICS RESISTANCE PROFILE OF BACTERIAL STRAINS PRODUCED OF BIOFILM ISOLATED FROM PATIENTS IN AL-DIWANIYA CITY, IRAQ. International Journal of Engineering Applied Sciences and Technology, 2019 Vol. 4, Issue 8, ISSN No. 2455-2143, Pages 295-299 